\title{
A Prospective Hospital-Based Study on the Clinico-Etiological Profile of First Episode Seizures in Children
}

\author{
Arpita Gogoi ${ }^{\star *}$, Aukifa Khamim Sabibahul Islam¹, Rita Panyang1, Pritikar Dowerah², Sutharson \\ Ramasamy $^{3}$, Manjit Boruah ${ }^{4}$
}

${ }^{1}$ Assistant Professor, ${ }^{2}$ Professor and Head, ${ }^{3}$ Post graduate trainee, Department of Pediatrics, ${ }^{4}$ Demonstrator, Department of Community Medicine, Assam Medical College, Dibrugarh, Assam, INDIA.

\begin{abstract}
Introduction: Seizures are one of the most common neurological causes of childhood hospitalization having significant mortality and morbidity. There is limited data regarding acute seizures episodes in the pediatric population from developing countries.

Aims: The current study aims to find the common etiologies of first episode seizure in children, and classify their types and outcomes in various age groups presenting to a tertiary center in Assam, North East India.

Settings \& design: A hospital-based prospective study was carried out in the Department of Pediatrics, Assam Medical College, Dibrugarh from $1^{\text {st }}$ October 2015 to $31^{\text {st }}$ March 2016 , and all children aged 1 month to 12 years admitted with the first episode of seizures over this six-month period, were evaluated.

Methods and materials: A pre-designed structured proforma was filled up for each subject and the variables studied were demographics, clinical presentations, laboratory tests, brain imaging studies, electroencephalography, diagnosis and outcome. The data was analyzed using SPSS for Windows version 16 , and $p$ value at $<.05$ was considered significant.

Results: A total of 65 patients were admitted for seizures with $40(61.5 \%)$ males and $25(38.5 \%)$ females. Among these patients, $45(69.2 \%)$ presented with fever and $53(81.5 \%)$ of children were less than 5 years of age.

Generalized tonic - clonic seizures was the most common seizure type $(73.8 \%)$. Febrile seizures $(40 \%)$, seizure disorder (12.3\%), CNS infections and neurocysticercosis were common etiologies. Abnormal brain images were noted in $7(43.75 \%)$ of 16 patients in whom neuroimaging was done, and most
\end{abstract}

\section{INTRODUCTION}

Seizures are the most common neurological symptom in children. The incidence is greatest in children less than 3 years of age. ${ }^{1}$ Five to ten percent of children suffer at least one episode of seizure in the first 16 years of life. Seizures account for about $2 \%$ of all pediatric emergency department visits. ${ }^{2}$ The incidence of epilepsy (recurrent unprovoked seizures) in children and adolescents seems relatively consistent across all populations, ranging from 50 to 100/100, 000 person-years. ${ }^{3}$ In most studies, febrile seizures is reported to be the commonest etiology in the pediatric population, primarily seen in children younger than 5 years of age. ${ }^{2-4}$

Central nervous system (CNS) infections are the main cause of provoked seizures and acquired epilepsy in the developing world. ${ }^{5}$ Acute seizures are common in meningitis, viral encephalitis and neurocysticercosis and in most cases are associated with increased mortality \& morbidity, including subsequent epilepsy. ${ }^{6-9}$ The standardized mortality rate (SMR) in patients with a newly common abnormality was neurocysticercosis in $4(25 \%)$. Conclusion: Febrile convulsions and CNS infections were common causes of seizures in febrile children, whereas seizure disorder and neurocysticercosis were the commonest causes in afebrile children.

EEG and neuroimaging should be advised in all afebrile children for the diagnosis of seizure disorder and neurocysticercosis respectively. In afebrile children less than five years of age, seizure disorder was commonly diagnosed, whereas NCC was more common in the greater than five year old children. Children diagnosed as seizure disorder require long term follow up studies including neurophysiologic studies.

Keywords: Convulsions, Febrile seizures, Neurocysticercosis, North East India.

\section{${ }^{*}$ Correspondence to:}

Dr Arpita Gogoi, Department of Pediatrics, Assam Medical College, Dibrugarh, Assam 786001.

Email: arpitag1000@yahoo.com

Article History:

Received: 15-04-2016, Revised: 22-04-2016, Accepted: 27-04-2016

\begin{tabular}{|l|c|}
\hline \multicolumn{2}{|c|}{ Access this article online } \\
\hline Website: & Quick Response code \\
www.ijmrp.com & \\
\hline DOI: & \\
10.21276/ijmrp.2016.2.3.025 & \\
\hline
\end{tabular}

diagnosed unprovoked seizure ranges from 2.5 to 4 , varying with the study population and design. The SMR is highest in the youngest patients and in those with symptomatic seizures. ${ }^{10}$ In most children with newly diagnosed epilepsy, the long-term prognosis of epilepsy is favorable, and patients with idiopathic etiology will eventually reach remission. ${ }^{11}$

It is not always immediately clear which laboratory and imaging examinations should be performed when children are admitted with seizures. Children admitted with new onset non-febrile seizures are often evaluated using neuroimaging, commonly cranial computed tomography (CT).12,13

Treating physicians have to decide for further investigations including septic screen, metabolic studies, lumbar puncture and electroencephalogram (EEG) for patients who present with a first attack of seizure. ${ }^{14}$ There is concern for cost of these investigations in resource poor developing countries. Misdiagnosis carries the potential risk of legal problems, family anxiety, 
excessive hospital stay, and possibly result in life-threatening events.

There are limited studies on causes and outcome of acute episode of seizure in children in developing countries like India. Most studies done so far have focused on epilepsy and clinical seizure types. ${ }^{15,16}$

Therefore, in this prospective study, we analyzed the prevalence of various etiologies, the clinical spectrum of seizure disorders and primary outcome of children admitted with a first attack of acute seizure disorder.

\section{MATERIALS AND METHODS}

\section{Patient population}

This was a prospective hospital-based study conducted in the Department of Pediatrics, Assam Medical College, Dibrugarh in North East India. During the study period of October 2015 to March 2016, ie, a period of six months, a total of 3151 children in the age group 1 month to 12 years were admitted in the Pediatric Department. Among these, 65 children (2.1\%) were admitted with the presenting complaint of first episode seizure and were included in the study.

Children with seizure onset after hospitalization, as well as children with previous history of seizures, known inborn errors of metabolism, malignancies, syndromes etc were excluded.

\section{Methodology}

The following information was obtained on a predesigned structured proforma from each patient: age (range from 1 month to 12 years), sex, demographics (ethnicity, religion, rural/urban/tea garden background, type of seizure, associated symptoms (fever, vomiting, diarrhea and headache), family history of seizure or epilepsy, birth and developmental history, Glasgow Coma Scale (GCS) score on admission, detailed neurological assessment, laboratory test results (white blood count, C-reactive protein, serum electrolytes, blood sugar and cerebrospinal fluid (CSF) analysis, neuroimaging ie cranial CT scan or cranial magnetic resonance imaging (MRI), electroencephalography (EEG), duration of hospital stay, final diagnosis and outcome. Final outcome was recorded in four categories; discharged after recovery, left against medical advice (LAMA), death, and referral to other institutions.

Patients were divided into two groups based on whether the seizure was with or without fever: Group 1 comprised patients with temperature on admission recorded as being greater than or equal to $38^{\circ} \mathrm{C}$, and Group 2 comprised patients with temperature less than $38^{\circ} \mathrm{C}$. Seizure type classification into generalized tonic-clonic (GTC), absence, myoclonic, partial and other seizure types was based on the Commission on Epidemiology and Prognosis, 1993 International League against Epilepsy. ${ }^{17}$ Febrile seizure was defined by the 1993 International League against Epilepsy as, "an epileptic seizure occurring in childhood after 1 month of age, associated with febrile illness not caused by an infection of the central nervous system (CNS), without previous neonatal seizure or previous unprovoked seizure, and not meeting criteria for other acute symptomatic seizure". In addition, febrile seizures were classified as simple febrile seizures or complex febrile seizures. A simple febrile seizure lasts less than 15 minutes, is initially generalized in nature, and occurs once during a 24-hour period. In contrast, a complex febrile seizure lasts more than 15 minutes, has focal features at any time, or recurs within a 24 -hour period. ${ }^{17}$
Other etiologies including meningitis and encephalitis were diagnosed on the basis of clinical and laboratory investigation and verified with standard reference textbooks. ${ }^{18}$

Furthermore, patients were divided into three age groups: 1 month to 6 months, 6 months to 5 years, and 5 to 12 years. Variables including age, sex, type of seizure, associated symptoms, developmental history, laboratory test results, neuroimaging examinations, EEG findings, duration of hospital stay, diagnosis and final outcome were compared between the febrile and afebrile groups. These variables were also compared among children of different age groups.

\section{Ethical committee approval}

Approval for the study was obtained from the institutional ethics committee (IEC) of The Assam Medical College Hospital.

\section{Sample size calculation}

Since previous similar studies in this part of North East India were not found, the incidence of children having fever with seizure was taken to be $50 \%$. It is estimated that for $90 \%$ confidence interval and, significance level $a=5 \%, P=54 \%, Q=46 \%$, allowable error $=10 \%$, required sample size was 65 .

$\mathrm{P}=$ percentage of children admitted with seizure and fever..$^{19}$

\section{Data analysis}

Descriptive statistics was used for the analysis. The data was analyzed using Statistical Package for the Social Sciences (SPSS) for Windows Version 16.0 (SPSS Inc; Chicago, IL, USA). The Chi-square test was used to examine the association between different variables and strength of the relationship with logistic regression. Odds ratios (OR) and their 95\% confidence intervals $(95 \% \mathrm{Cl})$ were calculated. $\mathrm{P}<0.05$ was considered as statistically significant. ${ }^{20,21}$

\section{RESULTS}

Demographics, clinical seizure types in children with seizure There were a total of 3151 patients admitted to the pediatric ward during the study period. Out of these patients $65(2.1 \%)$ children had first episode seizures as a presenting complaint. However, 245 children $(7.8 \%)$ in total were admitted with seizures (any episode) during this period.

Table 1: Relationship between age and presence of fever at presentation.

Comparison between age and fever

\begin{tabular}{|c|c|c|c|c|}
\hline \multicolumn{5}{|c|}{ Comparison between age and fever } \\
\hline & & & & Total \\
\hline & & afebrile & febrile & \\
\hline \multirow[t]{3}{*}{ Age } & $1-6$ months & 5 & 7 & 12 \\
\hline & 6 months to 5 years & 7 & 34 & 41 \\
\hline & more than 5 years & 8 & 4 & 12 \\
\hline Total & & 20 & 45 & 65 \\
\hline
\end{tabular}

Table 2: Relationship between gender and presence of fever on admission.

\begin{tabular}{llccc}
\hline \multicolumn{5}{c}{ Comparison between sex and presence of fever } \\
\hline \multirow{4}{*}{ Sex } & Male & afebrile & febrile & Total \\
& 12 & 28 & 40 \\
\multirow{3}{*}{ Total } & Female & 8 & 17 & 25 \\
& & 20 & 45 & 65 \\
\hline
\end{tabular}


Table 3: Types of seizures

\begin{tabular}{llccc}
\hline \multicolumn{4}{c}{ Comparison between Type of Seizure and Fever } \\
\hline \multirow{4}{*}{ Type of } & Generalized & 11 & 37 & 48 \\
Seizure & Focal & 3 & 3 & 6 \\
& Tonic & 1 & 1 & 2 \\
& Tonic clonic & 4 & 4 & 8 \\
& Absence & 1 & 0 & 1 \\
\multirow{3}{*}{ Total } & & 20 & 45 & 65 \\
\hline
\end{tabular}

Table 4: Age and gender-wise distribution

\begin{tabular}{|c|c|c|c|c|c|}
\hline \multicolumn{6}{|c|}{ Age-gender relationship } \\
\hline & & \multicolumn{3}{|c|}{ Age } & \multirow[b]{2}{*}{ Total } \\
\hline & & $\begin{array}{c}1-6 \\
\text { months }\end{array}$ & $\begin{array}{l}6 \text { months } \\
\text { to } 5 \text { years }\end{array}$ & $\begin{array}{c}\text { More than } \\
5 \text { years }\end{array}$ & \\
\hline \multirow[t]{2}{*}{ Sex } & Male & 4 & 29 & 7 & 40 \\
\hline & Female & 8 & 12 & 5 & 25 \\
\hline Total & & 12 & 41 & 12 & 65 \\
\hline
\end{tabular}

Among 65 children 53 (81.5\%) were in the age group 1 month to 5 years and of these 53 patients, fever was associated in $41(77.3 \%)$ of cases ( $p=.003)$. Fever was present on admission in $45(69.2 \%)$ of children. Afebrile seizure was common ie, in 8 out of $12(66.7 \%)$ in age group 5 to 12 years (Table 1). There were 40 (61.5\%) males and $25(38.5 \%)$ females with male to female ratio of 1.6:1 $(p=0.062)$ (Table 2). Generalized tonic clonic seizures was the commonest seizure type in this study with $48(73.8 \%)$ presenting with this type, and $37(57 \%)$ of them were febrile $(p<$ $0.001)$. These were followed by partial seizure $6(9.1 \%)$, absence $1(1.5 \%)$, tonic $2(3 \%)$. Other seizures types including tonic clonic comprised the remaining $8(12.3 \%)$ of cases.

\section{Analysis of patients based on age groups}

Figure 1: Seizures were more common in both males and females in the age group of 6 month to 5 years with 29 males (44.6\%), and 12 females (18.5\%) being present in this age bracket. (Table 4)

Table 5-7: Lumbar puncture was performed in 55 (84.6\%) children with abnormal reports in $6(11 \%)$. Neuroimaging was done in 16 $(24.6 \%)$ children admitted with seizure and included 8 (66.7\%) children in age group of 5 to 12 years. Neuroimaging had revealed abnormalities in 7 out of the 16 patients (43.75\%) in whom it was performed and most common finding was neurocysticercosis in 4 $(57 \%)$ children.

Electroencephalogram (EEG) was done in $16(24.6 \%)$ children and had abnormal reports in $9(56.25 \%)$ of cases. EEG abnormality was more in the age group of 6 months to 5 years with $5(62.5 \%)$ cases out of 8 . In the younger ( 1 to 6 months) and older (above 5 years) age groups, EEG abnormality was seen in $50 \%$ of cases where it was done.

Figure 2, Table 8,9: Febrile seizures was the commonest diagnosis with 26 cases $(40 \%)$ followed by meningitis (pyogenic/aseptic) and seizure disorder, both at 8 cases (12.3\%) in each category, neurocysticercosis $4(6.2 \%)$, and encephalitis $4(6.2 \%)$. Other diagnoses made were tubercular meningitis 2 $(3.1 \%)$, cerebral palsy $2(3.1 \%)$, hypertensive encephalopathy 1 $(1.5 \%)$, infantile spasms 2(3.1\%). Miscellaneous etiologies including electrolyte imbalance (hyponatremia) secondary to acute gastroenteritis, sickle cell disease with hypoxic seizures, intracranial hemorrhage, cyanotic congenital heart disease with hypoxic spells, subacute infarcts etc. that accounted for remaining $8(12.3 \%)$ of cases.

On presentation, $45(69.2 \%)$ had fever, of which $24(43.3 \%)$ were diagnosed as having febrile seizures. Acute encephalitic syndrome (AES) and meningitis (pyogenic/ tubercular/ aseptic) accounted for most of the remaining cases presenting with fever. Out of the $20(44.4 \%)$ remaining patients who presented with afebrile seizures, 7 (35\%) were diagnosed as having seizure disorder on EEG.

Table 5: Investigations: CSF analysis based on age

\begin{tabular}{llccccc}
\hline \multicolumn{2}{c}{ CSF_Analysis as per age } & & & \\
\hline & & \multicolumn{1}{c}{ Age } & & \\
& & $\mathbf{1 - 6}$ & $\mathbf{6}$ months & More than & Total \\
months & to 5 years & $\mathbf{5}$ years & \\
CSF & CSF not done & 2 & 5 & 3 & 10 \\
Analysis & CSF normal & 9 & 32 & 8 & 49 \\
& CSF protein high/ sugar low/ cell count high & 1 & 4 & 1 & 6 \\
Total & & 12 & 41 & 12 & 65 \\
\hline
\end{tabular}

Table 6: Investigations: Neuroimaging based on age

\begin{tabular}{llcccc}
\hline \multicolumn{5}{c}{ Neuroimaging results as per age } \\
\hline \multirow{4}{*}{ CTMRI } & $\begin{array}{c}\text { Age } \\
\text { Neuroimaging not done }\end{array}$ & $\begin{array}{c}\text { 1-6 } \\
\text { months }\end{array}$ & $\begin{array}{c}\text { 6 months } \\
\text { to 5 years }\end{array}$ & $\begin{array}{c}\text { more than } \\
\mathbf{5} \text { years }\end{array}$ & Total \\
& Neuroimaging normal & 9 & 36 & 4 & 49 \\
& Neurocysticercosis & 2 & 4 & 3 & 9 \\
& Intracranial/ subdural hemorrhage & 0 & 0 & 4 & 4 \\
& Infarct & 1 & 0 & 0 & 1 \\
& Tuberculoma/ CNS TB & 0 & 1 & 0 & 1 \\
Total & & 0 & 0 & 1 & 1 \\
\hline
\end{tabular}


Table 7: Investigations: EEG analysis

\begin{tabular}{|c|c|c|c|c|c|}
\hline \multicolumn{6}{|c|}{ EEG findings as per age } \\
\hline & & & Age & & \\
\hline & & $\begin{array}{c}1-6 \\
\text { months }\end{array}$ & $\begin{array}{l}6 \text { months } \\
\text { to } 5 \text { years }\end{array}$ & $\begin{array}{c}\text { more than } 5 \\
\text { years }\end{array}$ & Total \\
\hline \multirow[t]{3}{*}{ EEG } & EEG not done & 8 & 33 & 8 & 49 \\
\hline & normal EEG & 2 & 3 & 2 & 7 \\
\hline & Generalized seizure disorder & 2 & 5 & 2 & 9 \\
\hline Total & & 12 & 41 & 12 & 65 \\
\hline
\end{tabular}

Table 8: Age-wise final diagnosis

\begin{tabular}{|c|c|c|c|c|c|}
\hline \multicolumn{6}{|c|}{ Final diagnosis as per age-group } \\
\hline & & & Age & & \\
\hline & & $\begin{array}{c}1-6 \\
\text { months }\end{array}$ & $\begin{array}{l}6 \text { months } \\
\text { to } 5 \text { years }\end{array}$ & $\begin{array}{c}\text { more than } \\
5 \text { years }\end{array}$ & Total \\
\hline \multirow[t]{9}{*}{ Finaldiagnosis } & Seizure disorder & 2 & 3 & 3 & 8 \\
\hline & Febrile seizure & 2 & 24 & 0 & 26 \\
\hline & NCC & 0 & 0 & 4 & 4 \\
\hline & Meningitis (pyogenic/aseptic) & 3 & 5 & 0 & 8 \\
\hline & Meningitis (tubercular) & 0 & 1 & 1 & 2 \\
\hline & Acute Encephalitis Syndrome & 1 & 2 & 1 & 4 \\
\hline & Seizure under evaluation & 1 & 2 & 0 & 3 \\
\hline & Cerebrovascular accident & 1 & 1 & 0 & 2 \\
\hline & Others & 2 & 3 & 3 & 8 \\
\hline Total & & 12 & 41 & 12 & 65 \\
\hline
\end{tabular}

Table 9: Final diagnosis in relation to presence of fever at presentation

\begin{tabular}{llccc}
\hline \multicolumn{4}{c}{ Final diagnosis in relation to fever } \\
\hline \multirow{4}{*}{ Finaldiagnosis } & \multicolumn{3}{c}{ Febrile } & Total \\
& afebrile & febrile & \\
& Seizure disorder & 7 & 1 & 8 \\
& Febrile seizure & 2 & 24 & 26 \\
& NCC & 3 & 1 & 4 \\
& Meningitis (pyogenic/aseptic) & 1 & 7 & 8 \\
& Meningitis (tubercular) & 1 & 1 & 2 \\
& Acute Encephalitis Syndrome & 0 & 4 & 4 \\
& Seizure under evaluation & 1 & 2 & 3 \\
& Cerebrovascular accident & 0 & 2 & 2 \\
Total & Others & 5 & 3 & 8 \\
\hline
\end{tabular}

Table 10: Outcome in relation to final diagnosis Outcome as per final diagnosis

\begin{tabular}{|c|c|c|c|c|c|}
\hline \multicolumn{6}{|c|}{ Outcome as per final diagnosis } \\
\hline & & & utcome & & \\
\hline & & $\begin{array}{c}\text { Discharged/DOR } \\
\text { (discharged on } \\
\text { request) }\end{array}$ & Death & $\begin{array}{l}\text { DAMA/discharged } \\
\text { on request (DOR) }\end{array}$ & Total \\
\hline \multirow[t]{9}{*}{ Finaldiagnosis } & Seizure disorder & 7 & 0 & 1 & 8 \\
\hline & Febrile seizure & 24 & 0 & 2 & 26 \\
\hline & NCC & 4 & 0 & 0 & 4 \\
\hline & Meningitis (pyogenic/aseptic) & 4 & 3 & 1 & 8 \\
\hline & Meningitis (tubercular) & 1 & 0 & 1 & 2 \\
\hline & Acute Encephalitis Syndrome & 1 & 2 & 1 & 4 \\
\hline & Seizure under evaluation & 3 & 0 & 0 & 3 \\
\hline & Cerebrovascular accident & 2 & 0 & 0 & 2 \\
\hline & Others & 6 & 1 & 1 & 8 \\
\hline Total & & 52 & 6 & 7 & 65 \\
\hline
\end{tabular}

Outcome variables in different age group and relation to fever, gender, status and diagnosis

Table 10: Final outcome was noted as discharge, death during hospital stay, left against medical advice (LAMA) and those referred to other specialty center for further management. Six $(9.2 \%)$ of children died in hospital, $7(10.6 \%)$ had left against medical advice, and remaining $52(80 \%)$ were discharged after treatment. There was an insignificant difference in outcome between male and female; and those with or without fever.

All children with diagnosis of neurocysticercosis and febrile seizure were discharged after recovery. Children diagnosed as encephalitis and pyogenic/tubercular meningitis had high mortality rate, with only $50 \%$ and $62.5 \%$ being discharged respectively.

\section{DISCUSSION}

This was a hospital based prospective study of children admitted with acute episode of seizures in a tertiary care center in the north eastern region of India from October 2015 to March 2016. It aimed at studying demographics, clinical seizure types, etiologies and outcome of those children. Neonates and infants under 1 month of age were excluded from the study because frequently they have conditions unique to this age group like septicemia, hypoxic 
ischemic encephalopathy secondary to birth asphyxia, metabolic disorders etc which comprise one spectrum of disease..$^{22}$

\section{Demographics and clinical seizure types}

In our study, it was found that $2.1 \%$ of all pediatric inpatient admissions were due to first episode seizures, which is similar to the findings of Martindale et $\mathrm{al}^{2}$, whereas Chen et $\mathrm{al}^{5}$ reported the same at $1 \%$.

Most studies show high incidence of seizures in younger children with a decreasing frequency in older age group and more common in males. 2,5 Similar results were seen in the present study too; most children with seizures $(>80 \%)$ in our study were younger than 5 years of age. Males had higher prevalence $(61.5 \%)$ compared to females in our study, and the same has been reported in other studies; however this gender difference was not statistically significant. 5,9 Seizures coexisted with fever in $69.2 \%$ of cases in the present study, and the same was reported as $68 \%$ by Chen et $\mathrm{al}^{5}$, and $53.5 \% .{ }^{9}$ Most studies show generalized seizures

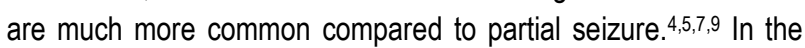
current study too, generalized tonic-clonic was the commonest seizure type $(73.8 \%)$ and found to have higher incidence among febrile children (77\%). GTCS was found to account for $71.2 \%$ of cases in the study done by Chen et al. ${ }^{5}$

Partial seizures represented only $9.2 \%$ of children in the current study, while it was common among children of developing countries in the setting of high incidence of neurocysticercosis, as per Basu et al. ${ }^{8}$

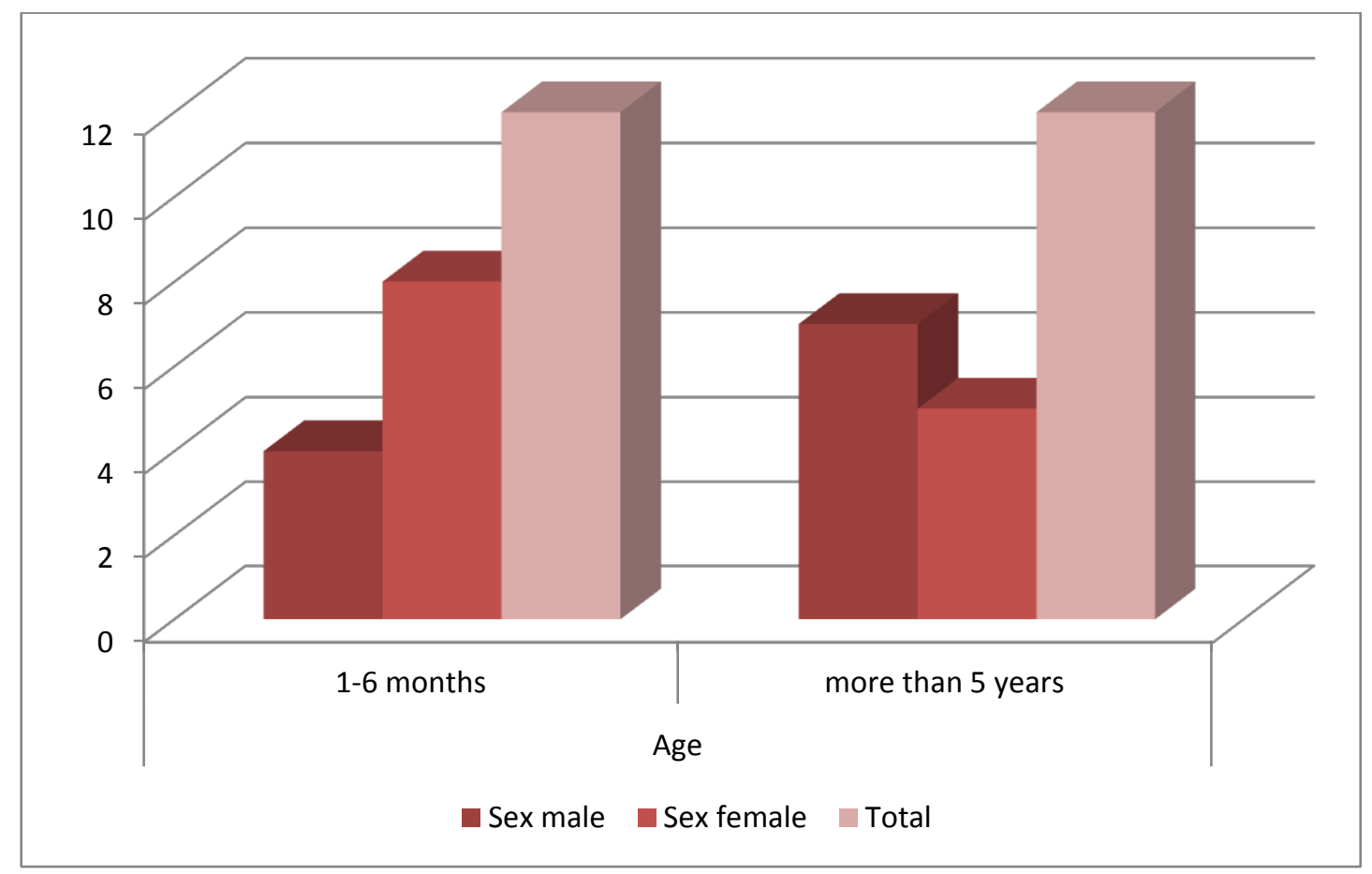

Figure 1: Age and gender distribution of cases

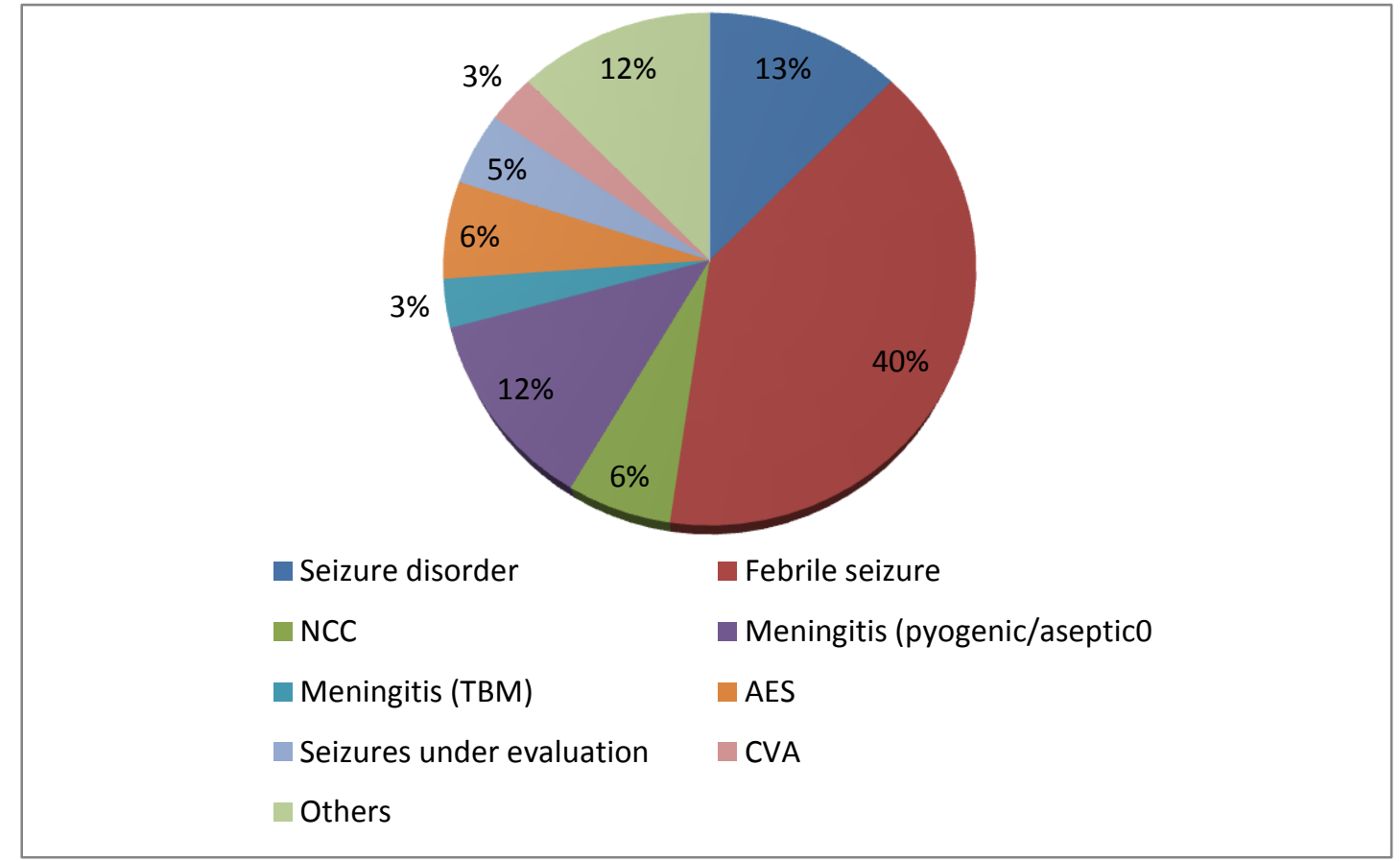

Figure 2: Final etiological diagnosis 


\section{Etiological profile}

Whether routine neuroimaging should be done in all children admitted with acute episode of seizure is debated. 5,12 In this study abnormal neuroimaging was present in 7 (43.75\%) and abnormal CT was found more in older afebrile children in the 5-12 years age group, mostly due to neurocysticercosis. There seems to be a role of routine neuroimaging in afebrile children with seizures in the age group more than 5 years in developing countries with high prevalence of neurocysticercosis. AAP recommends lumbar puncture for febrile seizure children aged less than 12 - months. ${ }^{22}$ CSF abnormality was detected in 11 to $12 \%$ of cases where it was performed, across all the three age groups. Lumbar puncture may be done in selected children guided by physical findings to rule out CNS infections older children. There are many possible etiologies of a first seizure attack in children, including infection, neurologic/ developmental causes, traumatic head injury, toxins, and metabolic disturbances. ${ }^{4-6}$ Febrile seizures have been reported to be one of the most common causes of seizure attack in children. ${ }^{2-4}$ We found that febrile seizures $(58.5 \%)$ were the main etiology of a first attack of seizure in children less than 5 years of age, and this was reported as $53 \%$ by Adhikari et al. ${ }^{9}$ Overall, febrile seizure was the commonest etiology in our study in children aged 1 month to 12 years $(40 \%)$ followed by seizure disorders confirmed neurophysiologically (12.3\%). The commonest etiology was febrile seizures $(62 \%)$ in the study by Chen et al, while it was $71 \%$ as found by Landfish et al. ${ }^{23}$

\section{Primary outcome of acute seizure}

Mortality rate during hospital course among children admitted with acute episode of seizure (9.2\%) was similar with reports from other developing countries. ${ }^{4}$ There was no significant difference in the outcome among males and females. Meningitis and encephalitis caused significant childhood mortality and morbidity. ${ }^{4,6}$ Children with diagnosis of encephalitis and those with status epilepticus had poor outcome with high mortality. ${ }^{24}$ Typical febrile seizure, neurocysticercosis and hypertensive encephalopathy had good outcome with majority of children discharged after recovery.

As evident from the current study, provoked seizures including CNS infections and neurocysticercosis account for majority of cases. Most of these might be prevented with improvement in immunization and sanitation. Since 2009 there is routine immunization for Japanese encephalitis that was introduced in selected districts of Assam ${ }^{25}$ and pentavalent vaccine has been introduced in 2015 in the Routine Immunization Programme in Assam. ${ }^{26}$ An attempt should be made to know the burden of other causative organisms for CNS infections and preventive measures should be undertaken. Health care facilities should be prepared for emergency management of seizures with intensive care units to decrease mortality and morbidity.

\section{LIMITATIONS OF THE STUDY}

Outcome was defined as mortality during hospital stay and we were unable to study morbidities like neurological dysfunction and impact on scholastic performance, as regular follow up could not be ensured owing to various factors like distance, monetary issues etc.

The study was conducted for a period of six months, and therefore the number of patients is low. It may be done over a longer period of time, perhaps also with follow up of the discharged patients to look at their neurological status, scholastic performance etc.

\section{CONCLUSION}

Acute episode of seizures is one of the commonest causes of hospitalization with high morbidity and mortality. It can be surmised from our study that most of acute symptomatic seizures are caused by febrile seizures, CNS infections like meningitis and encephalitis, neurocysticercosis which can be prevented with improvement in health care facilities. Those children who present with unprovoked seizures (ie seizure disorders as established by EEG) require long term follow up studies including serial neurophysiologic studies and neuroimaging (CT or MRI) for better understanding of the evolution of childhood seizure disorders.

\section{ACKNOWLEDGEMENTS}

We would like to acknowledge the support provided by Dr Helina Rahman, Professor of Pediatrics, Assam Medical College, Dibrugarh.

\section{REFERENCES}

1. Friedman MJ, Sharieff GQ: Seizures in children. Pediat Clin North Am 2006, 53:257-277.

2. Martindale JL, Goldstein JN, Pallin DJ: Emergency department seizure epidemiology. Emerg Med Clin North Am 2011 Feb, 29(1):1527.

3. Hauser WA: The prevalence and incidence of convulsive disorders in children. Epilepsia 1994, 35(suppl 2):S1-S6.

4. Idro R, Gwer S, Kahindi M: The incidence, aetiology and outcome of acute seizures in children admitted to a rural Kenyan district hospital. BMC Pediatr 2008, 8:5. http://www.biomedcentral.com/14712431/8/5.

5. Chen CY, Chang YJ, Wu HP: New-onset Seizures in Pediatric Emergency. Pediatr Neonatol 2010, 51(2):103-111.

6. Murthy JMK, Yangala R: Acute symptomatic seizures — incidence and etiological spectrum: a hospital-based study from South India. Seizure 1999, 8:162-165.

7. Huang CC, Chang YC, Wang ST: Acute Symptomatic Seizure Disorders in Young Children-A Population Study in Southern Taiwan. Epilepsia 1998, 39(9):960-964.

8. Basu S, Ramchandran U, Thapliyal A: Clinical profile and outcome of pediatric neuro-cysticercosis: A study from Western Nepal. J Pediatr Neurol 2007, 5:45-52.

9. Adhikari S, Sathian B, Koirala DP, Rao KS:Profile of children admitted with seizures in a tertiary care hospital of Western Nepal. BMC Pediatrics, 2013, 13:43 DOI: 10.1186/1471-2431-13-43

10. Allen Hauser W, Beghi E: First seizure definitions and worldwide incidence and mortality. Epilepsia 2008, 49(Suppl. 1):8-12.

11. Geerts A, Arts WF, Stroink H, Peeters E, Brouwer O, Peters B, et al: Course and outcome of childhood epilepsy: A 15-year follow-up of the Dutch Study of Epilepsy in Childhood. Epilepsia 2010, 51(7):1189-1197.

12. Goldstein JL: Evaluating new onset of seizures in children. Pediatr Ann 2004, 33(6):368-374.

13. Bautovich T, Numa A: Role of head computed tomography in the evaluation of children admitted to the paediatric intensive care unit with new-onset seizure. Emerg Med Australas 2012, 24(3):313-320. 14. Sharma S, Riviello JJ, Harper MB, Baskin MN: The role of emergent neuroimaging in children with new-onset afebrile seizures. Pediatrics 2003, 111(1):1-5. 


\section{Arpita Gogoi et al. Clinico-Etiological Profile of First Episode Seizures in Children}

15. Udani V: Pediatric epilepsy - an Indian perspective. The Indian Journal of Pediatrics April 2005, Volume 72, Issue 4, pp 309-313

16. Senthil A, Gopalkrishna G, Parthasarathy S: Epilepsy in India I: Epidemiology and public health. (Internet). Annals of Indian Academy of Neurology 2015 Volume: 18 Issue: 3 Page: 263-277. (Date accessed: $4^{\text {th }}$ April 2016)

17. Commission on Epidemiology and Prognosis: International League Against Epilepsy. Guideline for epidemiologic studies on epilepsy. Epilepsia 1993, 34:592-596.

18. Prober CG, Dyner LL: Central nervous system infections. In Nelson Textbook of Pediatrics. 19th edition. Edited by Kliegman RM, Stanton BF, St.gem JW. Philadelphia PA: W.B. Saunders; 2012:2088. 19. Clare $R$, Copas A, Eldrige $S$ : Methods for sample size determination in cluster randomized trials. Int J Epidemiol. 2015 Jun; 44(3): 1051-1067.

20. Pye V, Taylor N Clay Williams R, Braithwaite $\mathrm{J}$ : When is enough, enough? Understanding and solving your sample size problems in health services research. BMC Res Notes 2016 Feb 12; 9(1):90. doi: 10.1186/s13104-016-1893-x.

21. Perla RJ, Provost LP, Murray SK: Sampling considerations for health care improvement. Qual Manag Health Care. 2014 OctDec;23(4):268-79. doi: 10.1097/QMH.0000000000000042.

22. Academy of Pediatrics. Provisional Committee on Quality Improvement, Subcommittee on Febrile Seizures: Practice parameter: the neurodiagnostic evaluation of the child with a first simple febrile seizure. Pediatrics 1996, 97:769-772.

23. Santos MI, Nzwalo H, Monteiro JP, Fonseca MJ: Convulsive status epilepticus in the pediatric emergency department: five year retrospective analysis. Acta Med Port 2012, 25(4):203-206.

24. Landfish N,Gieron Korthals M, Weibley RE, Panzarino V: New onset childhood seizures. Emergency department experience.
University of South Florida College of Medicine, Tampa. The Journal of the Florida Medical Association [1992, 79(10):697-700]

25. Operational Guide Japanese Encephalitis Vaccination in India September 2010; Immunization Division Department of Family Welfare Ministry of Health and Family Welfare Government of India. (Date accessed: $5^{\text {th }}$ April 2016). Available from http://www.iapcoi.com/hp/Dec\%2025th/Guidelines-JapaneseEncephalitis,\%20MoHFW,\%20September\%202010[2].pdf

26. Global Alliance for Vaccines and Immunization (GAVI). November 2014. Pentavalent vaccine introductions represent historic milestone for immunisation in India. (Date accessed: $9^{\text {th }}$ April 2016). Available from http://www.gavi.org/Library/News/Statements/2014/Pentavalentvaccine-introductions-represent-historic-milestone-for-immunisationin-India/

Source of Support: Nil. Conflict of Interest: None Declared.

Copyright: (c) the author(s) and publisher. IJMRP is an official publication of Ibn Sina Academy of Medieval Medicine \& Sciences, registered in 2001 under Indian Trusts Act, 1882.

This is an open access article distributed under the terms of the Creative Commons Attribution Non-commercial License, which permits unrestricted non-commercial use, distribution, and reproduction in any medium, provided the original work is properly cited.

Cite this article as: Arpita Gogoi, Aukifa Khamim Sabibahul Islam, Rita Panyang, Pritikar Dowerah, Sutharson Ramasamy, Manjit Boruah. A Prospective Hospital-Based Study on the ClinicoEtiological Profile of First Episode Seizures in Children. Int J Med Res Prof. 2016; 2(3):108-14. 